\title{
Chronic wound management and research
}

This article was published in the following Dove Press journal:

Chronic Wound Care Management and Research

13 March 2014

Number of times this article has been viewed

\section{Marco Romanelli}

Wound Healing Research Unit, Division of Dermatology, University of Pisa, Pisa, Italy

Correspondence: Marco Romanelli

Division of Dermatology,

Department of Clinical and Experimental

Medicine, University of Pisa Via Roma,

67,56126 Pisa, Italy

Emailm.romanelli@med.unpi.it
I would like to share with you a new open access peer-reviewed journal - Chronic Wound Care Management and Research, published by Dove Medical Press.

Chronic Wound Care Management and Research is an international, peer-reviewed, open-access online journal publishing original research, case reports, reviews, editorials, and commentaries on the management of chronic wounds and major issues related to chronic wound management.

There are several reasons to justify a new journal in wound care. The first is that the prevalence of chronic wounds in long-term conditions has become a major resource demand. Further, the technology is developing and a large number of very interesting research studies will have to display their results with reference to the current literature. The intent of the journal is to provide clinicians and researchers with a tool to disseminate their research or personal experiences to the wider public as well as to review interesting topics in wound healing.

Chronic wound research has progressed impressively over the past few years. New insights into molecular and inflammatory aspects of their pathogenesis and the study of novel therapies have revealed basic cellular and molecular mechanisms underlying chronic vascular, metabolic, and inflammatory disorders.

Submissions to this online journal in the form of original research or reviews are currently being invited.

\section{Disclosure}

The author has no conflicts of interest to disclose.

\section{Publish your work in this journal}

Chronic Wound Care Management and Research is an international, peer reviewed, open access, online journal publishing original research, reviews, editorials, and commentaries on the causes and management of chronic wounds and the major issues related to chronic wound management. Topics also include chronic wounds as comorbidities to other conditions, patient adherence to therapy, and the economic burden of chronic wounds. The manuscript management system is completely online and includes a very quick and fair peer review system, which is all easy to use. Visit http://www.dovepress.com/testimonials.php to read real quotes from published authors. 